\title{
The Effect of Political Connection and Earnings Management on Management Compensation
}

\author{
Riky Rizki Junaidi ${ }^{1}$ and Sylvia Veronica Siregar ${ }^{1}$ \\ $\left\{\right.$ rikyrizkijunaidi@gmail.com ${ }^{1}$ \} \\ ${ }^{1}$ University of Indonesia, Jl. Margonda Raya 16424, Indonesia
}

\begin{abstract}
This research aims to examine the direct effect of political connection and earnings management on management compensation as well indirect effect of political connection on management compensation through earnings management. There were three measures of earnings management used in this research, namely accrual, real, and aggregate earnings management. Samples of this research are non-financial companies listed in Indonesia Stock Exchange in the period of 2014-2016 with 337 observations. We find that real earnings management has a significant positive effect to management compensation. However, there is no evidence that political connection has an influence on earnings management and political connection on management compensation. Moreover, there is no evidence on the indirect effect of political connection on management compensation through earnings management.
\end{abstract}

Keywords: Political Connection, Earnings Management, Management Compensation

\section{Introduction}

Current intense business competition and the environment uncertainty force the management to work more efficiently and efficiently in efforts to maintain the existence of the company and improve management performance to achieve optimal results. Earnings is a component of financial statements that becomes the centre of attention and the basis for stakeholders decision-making, for example to assess management performance as a basis to compensate management. The use of earnings as a basis of management compensation may provide incentive for management to engage in earnings management. Management may choose accounting methods that can shift earnings from the future to the present time with the aim to increase current earnings to achieve certain earnings target can be accomplished.

Jensen \& Meckling (1976) stated that agency relationship is a contract between the manager (agent) with company owner (principal). Manager, as the one who manages the company, has more inside information and knows better about the future prospect of the company compared to the owner (shareholders). Because of that, the management has the obligation to gives signals regarding company's condition to the owner. Financial statements are meant to be used by many, including the management itself. However, ones most concerned with the financial statements are external users (outside the management). This situation will trigger a condition called as information asymmetry, a condition in which there is an imbalance of information gains between the management as the prepaper with shareholders and stakeholder in general as information user.

There are a lot of cases caused by the practices of earnings management, such as cases of Enron, Worldcom, Global Crossing, HIH, Tyco, case of PT Bank Lippo Tbk, case of PT. Citra Marga Nusapala Persada, Bank Duta, Xerox, PT. Perusahaan Gas Negara, Merck and PT. Kimia Farma Tbk. There are a lot of motivations for a company to practice earnings 
management, for instance to meet profit target ; to satisfy external parties' expectancy to company's performance; to smooth the profit reported by the company; to fulfill all criteria required for loans; and also as window dressing to maximize sales of shares in IPO (Initial Public Offering). Besides that, earnings management are also practiced by the management for its own interests, for example bonus sharing based on the profits reported in financial statements. As a result, opportunistic earnings management practices will mislead users of financial statements in assessing company's performance, because the financial statements do not represent the actual condition of the company.

Related to earnings management behaviors, Healy \& Wahlen (1999) recorded two types of earnings management usually used by the manager of a company, both are accrual earnings management and real earnings management. Accrual earnings method is done by adjusting the accounting methods and accounting policies to produce the desired profits (Dechow and Skinner, 2000), and real earning management is done by manipulating the company's real activities, so the company can report the desired profit without causing suspicions from other parties, because the practice is done within the company's operational activities (Roychowdhury, 2006). Real earnings management costs higher than accrual earnings management because it directly impacts the company's cash flow, such as massive discounting, provision of soft loans, and reduction of current year's discretionary expenses ((Roychowdhury, 2006; Cohen \& Zarowin, 2010).

(Ding and Chou, 2015) examined the relationship between political connections with management compensation with Chinese companies as samples. The study found evidences that managers with political connections will positively and/or negatively affect the compensation received from private companies, not government-owned companies. The study also explained that by the political connections owned by the manager, then there will be increase in company's performance, but only if the owners do not have substantial political connections, and vice versa.

Companies with political connections do not have much pressure to practice transparency, therefore information asymmetry in companies with political connections will become bigger and also trigger earnings management practices ((Chaney et al. 2011)). Besides that, another characteristic of companies with political connections is the low risk of detection if opportunistic actions are taken. (Kim and Zhang, 2016), hence the chance and incentive of the management to practice earnings management will be bigger. Some studies have been conducted to find the the relationship between political connection and earnings management. Braam et al (2015) investigates whether companies with political connections tend to practice accrual-based earnings management or real-based. Morck et al (2000) shows that the influence of companies' political connections are higher in countries with higher corruption rates. Fisman (2001), Leuz \& Oberholzer-Gee, (2006) measured political connections based on company's proximity with the family of ex-president Soehartoe, although it is already irrelevant with the current condition. With the newer and more accurate measurement of political connections, this research hopefully will contribute to the results of the previous researches with newest and more accurate variables measurements.

Although there have been many studies conducted to examine the influence of political connection to management compensation, but the results are still inconclusive. Varied results are possible because the influence of political connection to management compensation can be indirect. Therefore, this research uses earnings management (real, accrual and aggregate ) as variables mediating the influence of political connection to management compensation. 


\section{Methodology}

In this research, the population used is all companies listed in Indonesia Stock Exchange (BEI) consecutively in the period of 2014-2016. The period is chosen on the consideration of term of office for officials elected in 2014 election, so it will be easier to match data of officials, governors, ministers, legislative members or parties' executives with data of members in sample companies' boards of directors. Besides that, another reason is to minimize the effects of regime differences which can affect the testing results of this research (Fisman, 2001;Leuz \& Oberholzer-Gee, 2006). In this research, the data needed includes financial data, data of analysis results of companies' annual financial statements, data of sample companies' political connections. To obtain the data, there are few sources used to obtain data, including : financial data obtained from Indonesian Capital Market Electronic Library (ICAMEL), corporates' annual reports and datastream; and data related to political connections, obtained from the analysis of biodata and profiles of members of board of directors found in companies' annual reports and the results of matching the names with the lists of both local and state officials, legislative members, and political parties' executives. Samples are selected by using purposive sampling, in which the samples selected must fulfill the criteria as the following:

- Eliminate all companies categorized in financial services industry, because this industry is more highly regulated than companies in other industries. (Lanis \& Richardson, 2012; Favotto et al, 2016)).

- Companies with negative equity are because they can create confounding effects and are harder to be interpreted, for negative equity is one of the signs of companies in financial distress ((Adhikari et al, 2006).

- One full year of reporting period and reporting period ends on $31^{\text {st }}$ of December ((Harymawan et al, 2018))

- Have all data needed to calculate the variables used in this research.

\section{Result And Discussion}

The population of this research is consisted of all companies listed in Indonesia Stock Exchange (BEI) during the period of years 2014-2016. Then, samples are filtered with the criteria, and from the population of 1.582 company-year, 337 company-year samples are obtained $(21,30 \%)$. Result of descriptive statistics for earnings management models can be observed from table 4.1. For accrual earnings management variable, sample companies have the average discretionary accrual value of 5,34\% and standard deviation of $4,82 \%$. Higher discretionary accrual value means higher indications that a company practices accrual earnings management. The lowest and the highest value is $0,0004 \%$ and $31,34 \%$, respectively.

For real earnings management, descriptive statistics result show an average of $13,66 \%$. From that positive value, it can be said that there are indications that sample companies practice real earnings management by discount to increase sales, reduce discretionary expenses or over production so that the company's profits in the current year is bigger than in the normal period. Real earnings management variable's values has a minimum of $0,0004 \%$. From this result, the value of earnings management variable is considered to be appropriate to describe real earnings management practices done through companies' operational activities. The maximum value of real earnings management variable is $188,27 \%$. The component of real earnings management which contribute the most to the biggest value of earnings management 
variable is abnormal production, which is done through overproduction process with the aim to to reduce cost of goods sold in the current year.

For the result of descriptive statistics of aggregate earning management, the average is close to 1 because the aggregate earnings management values is calculated as the total of accrual earnings management decile plus real earnings management decile. The decile sort the magnitude of accrual earnings management and real earnings management in the range 0-1, therefore firm with the highest accrual earnings management and real earnings management will have decile value close to 1 .

Table 1. Results of Descriptive Statistics

\begin{tabular}{cccccc}
\hline Variable & $\mathrm{N}$ & Mean & Std.Dev & Min & Max \\
\hline AbsAEM & 337 & 0,0534 & 0,0482 & 0,0004 & 0,3134 \\
\hline AbsREM & 337 & 0,1366 & 0,1582 & 0,0004 & 1,8827 \\
\hline AbsEM_ALL & 337 & 0,9998 & 0,4654 & 0,0029 & 1,9851 \\
\hline CPC & 337 & 0,3220 & 0,1032 & 0,0000 & 0,7500 \\
\hline COMPEN & 337 & 4,8798 & 1,9449 & 1,4059 & 21,1861 \\
\hline SIZE(Juta Rp) & 337 & 29,4024 & 1,4285 & 24,4081 & 32,8218 \\
\hline LEV & 337 & 0,2685 & 0,1701 & 0,0012 & 0,8105 \\
\hline ROA & 337 & 0,0440 & 0,0827 & 0,1568 & 0,5929 \\
\hline AUDITOR & 337 & 0,4658 & 0,4995 & 0,0000 & 1,0000 \\
\hline MBV & 337 & 2,8932 & 3,6968 & 0,0637 & 17,4852 \\
\hline BODSIZE & 337 & 5,4391 & 2,0492 & 1,0000 & 17,0000 \\
\hline LnEMP & 337 & 7,2990 & 1,4363 & 3,2958 & 10,4193 \\
\hline
\end{tabular}

Explanation:

ABSAEM : Absolute value of accrual earnings management's residual value;

ABSREM : Absolute value of real earnings management's residual value;

EM_ALL : Sum of absolute values of AEM's and REM's decil values ;

$\mathrm{CPC} \quad$ : Percentage of members of board of commissioner and directors with political connections;

COMPEN : Natural logarithm of board of directors to total members of board of directors ;

SIZE : Company size evaluated by total assets (in millions of rupiah);

LEV : Debt to total assets ratio;

MBV : Market value to book value of equity ratio;

BODSIZE : Size of board of directors evaluated by the number of directors I in the board ;

LnEMP : Number of employees measured by natural logarithm;

AUDITOR : Auditor quality measured by dummy 1 if affiliated with Big 4, 0 otherwise;

ROA : return on assets from the ratio of net profit to total assets.

On the other hand, firm with the lowest accrual earnings management and real earnings management will have decile value close to 0 . Therefore, when the decile values of accrual earnings management and real earnings management are added, it will result in value within the range of $0-2$. For the statistic descriptive, standard deviation of aggregate earnings management is $46,54 \%$. The lowest score of aggregate earnings management is 0,0029 , while the highest score is 1,9851. the higher the value of EM_ALL, the higher the indication of aggregate earnings management, both via accrual earnings management and real earnings management.

Political connections variable (CPC) is considerably varied if observed from the results of descriptive statistics, where the average of companies with political connections is $32,20 \%$ 
with standard deviation of $10,32 \%$. Minimum value is $0,00 \%$ and maximum value is $75 \%$ which means that more members of board of directors have political connections. The higher the percentage of CPC, the higher the influence of political connections owned by board of directors is. For management compensation variable, descriptive statistics results show the minimum value of 1,4059 to the maximum value of 21,1861 with average 4,8798 and standard deviation of 1,9449 which means that the compensation received by the board of directors are considerably varied research can be generalized to companies with various sizes The second control variable LEV or total debts to total assets ratio has an average of $26,85 \%$ which means that the average debts sample companies is $26,85 \%$ from the total assets. The maximum value, with leverage of $81,05 \%$, is owned by telecommunication network infrastructure provider company. Although it has high leverage, but the company claimed that they and the creditors feels secure, as they are supported by the secured long-term contracts with operators companies and good hedging policies (Market Bisnis, 2016). The third control variable MBV has an average of 2,8932, minimum value of 0,0637 and maximum value of 17,4852. Other control variables, such as AUDITOR as a proxy for auditor quality, the average for sample companies used in the earnings management model is $46,58 \%$ which means that $46,58 \%$ of all samples are aaduited by KAP affiliated with Big 4, while the rest or around $53,42 \%$ of the samples are audited KAP Non Big 4 . Variable AUDITOR is a dummy variable. Value of 1 shows that the company is audited by KAP Big 4, 0 otherwise. For the control variable used only for real earnings management, ROA or return on assets, which is used as a proxy for company's performance, the average from sample companies are $4,40 \%$ which shows that every Rp 1 of asset owned by the company capable of producing Rp 0,04 as profits. One of the cause of the small value of the average is that there are 56 out of 337 sample companies reported negative profits.

For the control variables for management compensation only, BODSIZE dan LnEMP, the averages are $543 \%$ and $729 \%$ respectively, while the minimum values are $100 \%$ and $329 \%$ respectively. The highest ROA value from the samples is $59,29 \%$ which means that for every $\mathrm{Rp} 1$ of assets, the company produce Rp 59,29 in profit. In that year, the company had a rapid increase in the revenues by selling shares from its subsidiary and increase in operating revenues with value of $\mathrm{Rp} 802.810 .000 .000,00$, thus this company has the best performance compared to other samples for real earnings management in the period of 2014-2016 (Lupiyoadi, 2014).

\section{Conclusions}

This research aims to examine the influence of political connection to management compensation mediated by earnings management (all real, accrual and aggregate) based on agency theory. Earnings management practices are considered to be unethical because they can misled the users of financial statements by delivering financial statements that do not represent the actual condition. Furthermore, earnings management practices can lead the management to receive personal gains and inflict losses to shareholders. The following are few conclusion based on the testing results:

- There is no direct influence of political connection to earnings management found. This result is possibly caused by the weaknesses of the measurement models, so the absolute value of real, accrual earnings management residual values and also the decile of the sum of accrual and real earnings management do not reflect the actual accrual earnings management practices. 
- There is significantly and negatively influence of political connection to management compensation to all models of earnings management (accrual, real and aggregate). This proves that political connections of the board of directors influence the compensations they receive. However this result shows that political connections do not increase the compensation they receive.

- Real earnings management is proved to significantly and positively influence management compensation. However, management compensation is proved to have no influence to accrual and aggregate earnings management.

- There is no indirect influence of political connection to management compensation through real, accrual and aggregate earnings management.

\section{References}

[1] Adhikari, A., Derashid, C. and Zhang, H. (2006) 'Public Policy, Political Connections, and Effective Tax Rates: Longitudinal Evidence from Malaysia', Journal of Accounting and Public policy. Elsevier, 25(5), pp. 574-595.

[2] Braam, G., Nandy, M., Weitzel, U. and Lodh, S. (2015) 'Accrual-Based and Real Earnings Management and Political Connections', The International Journal of Accounting. Elsevier, 50(2), pp. 111-141.

[3] Chaney, P. K., Faccio, M. and Parsley, D. (2011) 'The Quality of Accounting Information in Politically Connected Firms', Journal of accounting and Economics. Elsevier, 51(1-2), pp. 58-76.

[4] Cohen, D. A. and Zarowin, P. (2010) 'Accrual-Based and Real Earnings Management Activities Around Seasoned Equity Offerings', Journal of accounting and Economics. Elsevier, 50(1), pp. 2-19.

[5] Dechow, P. M. and Skinner, D. J. (2000) 'Earnings Management: Reconciling The Views of Accounting Academics, Practitioners, and Regulators', Accounting horizons, 14(2), pp. 235-250.

[6] Ding, D. and Chou, M. C. (2015) 'Stowage Planning for Container Ships: A Heuristic Algorithm To Reduce the Number of Shifts', European Journal of Operational Research. Elsevier, 246(1), pp. 242-249.

[7] Favotto, F., Bozzolan, S. and Parbonetti, A. (2016) Economia Aziendale: Modelli, Misure, Casi. McGraw-Hill education.

[8] Fisman, R. (2001) 'Estimating the Value of Political Connections', American economic review, 91(4), pp. 1095-1102.

[9] Harymawan, I., Agustia, D. and Agung, A. K. (2018) 'Characteristics of Politically Connected Firms in Indonesia'.

[10] Healy, P. M. and Wahlen, J. M. (1999) 'A Review of The Earnings Management Literature and Its Implications for Standard Setting', Accounting horizons, 13(4), pp. 365-383.

[11] Jensen, M. C. and Meckling, W. H. (1976) 'Theory of The Firm: Managerial Behavior, Agency Costs And Ownership Structure', Journal of financial economics. Elsevier, 3(4), pp. 305-360.

[12] Kim, J. and Zhang, L. (2016) 'Accounting Conservatism and Stock Price Crash Risk: Firm-Level Evidence', Contemporary Accounting Research. Wiley Online Library, 33(1), pp. 412-441.

[13] Lanis, R. and Richardson, G. (2012) 'Corporate Social Responsibility and Tax Aggressiveness: An empirical analysis', Journal of Accounting and Public Policy. 
Elsevier, 31(1), pp. 86-108.

[14] Leuz, C. and Oberholzer-Gee, F. (2006) 'Political Relationships, Global Financing, and Corporate Transparency: Evidence from Indonesia', Journal of financial economics. Elsevier, 81(2), pp. 411-439.

[15] Lupiyoadi, R. (2014) 'Pemasaran Jasa'. Universitas Terbuka.

[16] Morck, R., Yeung, B. and Yu, W. (2000) 'The Information Content of Stock Markets: Why Do Emerging Markets Have Synchronous Stock Price Movements', Journal of financial economics. Elsevier, 58(1-2), pp. 215-260.

[17] Roychowdhury, S. (2006) 'Earnings Management Through Real Activities Manipulation', Journal of accounting and economics. Elsevier, 42(3), pp. 335-370. 